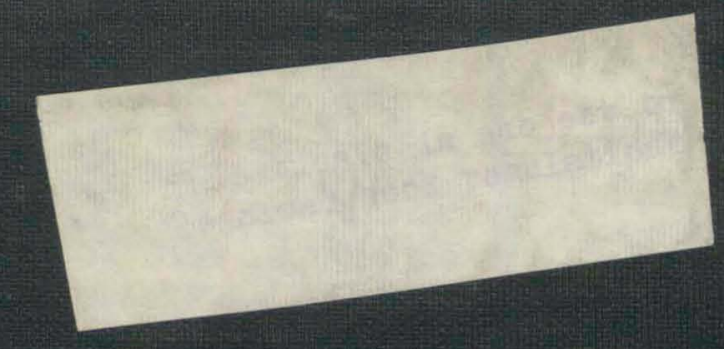

UM Libraries Depository

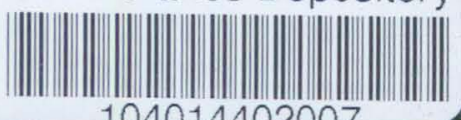




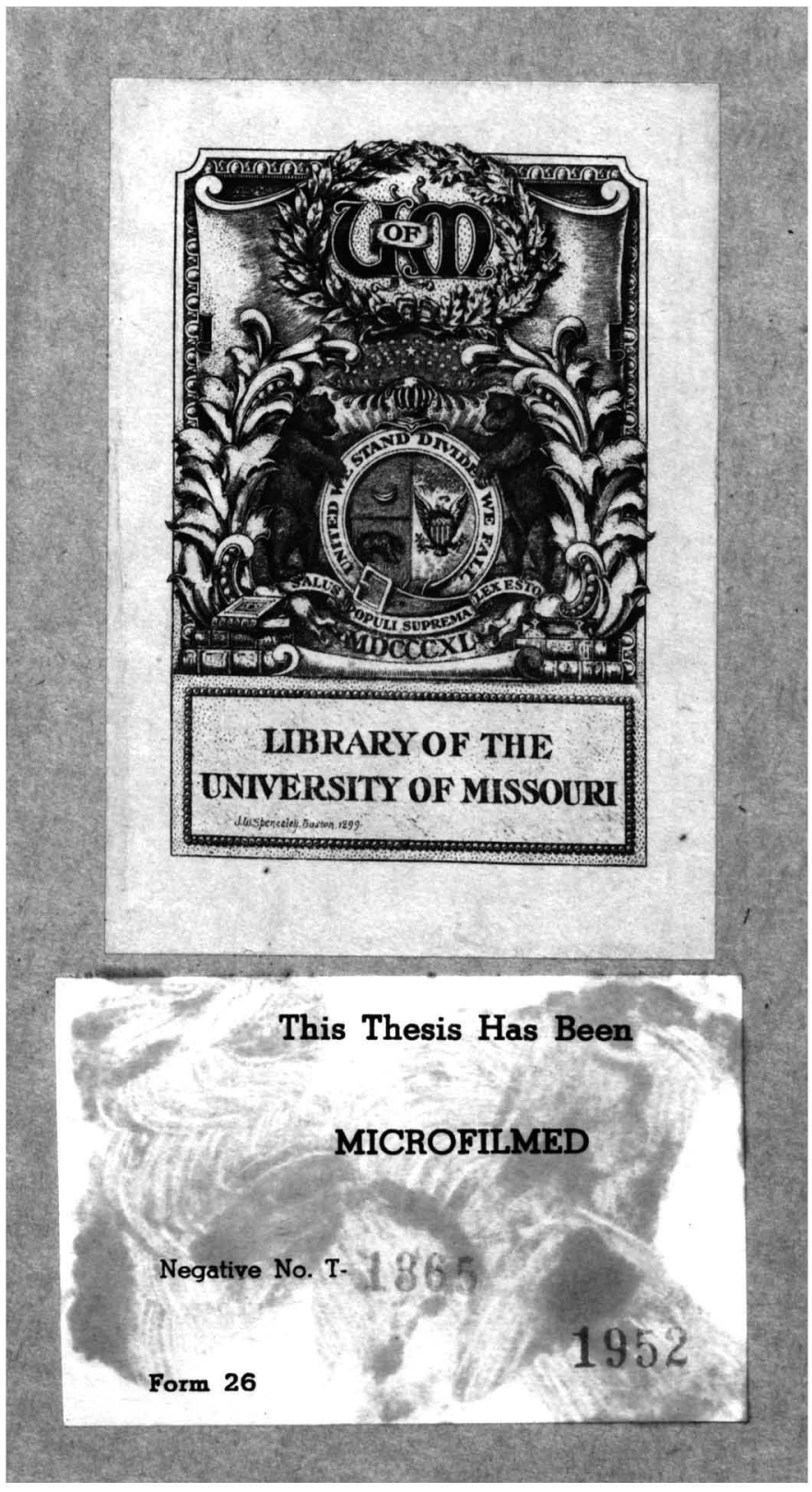






THE PHYSIOLOGICAL SIGNIFICANCE OF THE ANATON ICAL CHANGES PRODUCEL IN NERVE CELLS BY THE ACTION OF CERTAIN BACTERIAI TOXINS.

$\dot{b y}$

Ralph Rayburn Simmons, A.B.

SUBMITTED IN PARTIAL FULFIIMENT OF THE REQUIREMENTS FOR THE DEGREF: OF MASTER OF ARTS

In tine

GRADUATE SCHOOL

of tine

UNIVERSITY OF MISSOURI

1914 

Synopsis.

Introduction.

The distinction anatonically and prysiologically between functional activity and depression of suck activity, as applied to the nerve cell. source of material.

Stapky lococcus group.

Dipintheria group.

Rabies group.

Microscopic Tecinic.

Anatomical and physiological analys is of the material.

Review of the deferential counts with physiolopical deductions.

Tables.

Nos. I, II, III, IV.

Review of Iiterature.

staphy lococcus.

Diphtheria.

Rables.

summary and conclusions.

Blbliagraphy .

Genera.1.

Diphtieria.

Rabies. 

INTRODUCTION.

During the last four years there has been a considerable amount of originel invertigation in this laboratory of the chanfes in nerve cells resulting from wany forms of stimlation, both normal, and in the sense of being unusual, abnornal. The object of the research undertaken $b_{y}$ the writer was to ascertain the possible correlation of the anatouical changes produced in the nerve cell frow the action of certain bacterial toxins with the changes produced by other forms of stimulation. As a basis of comparison for the proper interpretation of the changes noted in the nerve cells after subjection to the ection of the bacterial toxins, it was necessarily important to ascertain, as nearly as possible, the anatomical changes during ordinary activity, that is, activity occuring spontaneous in daily life.

Primarily nerve cells are of a highly specialized tyne and this specialization is one of function. 

All other changes than those of function are thus eliminated in the case of the adult cell in respect to a biological process (Dolley 1914). Since we know this fact it simplifies the problem of nerve cell activity, and places it in a unique position for experimental study that perhaps is not approached by any other cells. The present experimental work has been devoted to the changes in the Purkinje cell, a highly differentiated type of nerve cell. This is the cell fom which the wost of the previous conclusions have been drawn.

As regaras the functioning nerve cell there are two possible changes primarily,-- one of functional activity and one of depression of such activity. The proof of this statement will be more fully discussed in the naragraph on the nature of stimuli.

By the functional activity is meant the work of the cell, while by deprossion, in the strict sense, the blocking or inhibit ion of that work. These terms have apparently so little in common that they seem almost to be diametrically opposite, yet when the fact is considered that the end result of both processes is a complete cessation of 

function, a more exhaustive differentiation of these two phenomena is necessary.

Verworn in 1896 clearly advanced the idea that there was a difference between the depression of function due to the accunulation of waste products within the cell and the depression of function due to the actual consumption of the cell substances necessary for life. In the case of the latter, every manifestation of function calls for an expenditure of vital subctance. If the demand for this expenditure of protoplasmic substance is core rapid than the retabolism of this substance can be perforwed, the finel result will be a total loss of protoplasmic substances necessary for the waintenance of life. The intermediate stages of such a process mej be looked upon as fatigue, while the end result is one of exhaustion. The exhaustion obtained in this menner may, in the sense of incapecitating the cell for further work, be looked upon as a depression. This complete depression is an exhaustion due to functional activity, while, as in the case of the accumulation of waste products, there may be a complete stoppage of function without substantive loss. The latter case,then, is a depression of functional activity in the more usual sense. 

To summarize, exhaustion resulting from functional activity may be looked upon as an inability unon the part of the cell to carry on its normal function which is aue to the actual destruction of the protoplaswic material necessary for this activity. On the other hand, depression proper may be consiaered as a stoppage of functional activity, or in its intermediate ctages a decrease of the normal intensity of vital phenomena, due to the blocking of the cellular processes by the waste products of metabolism. However, both proouce the sace result in the final effect on outward function, that is, in external work.

But, as Verworn points out in his General Physiology, different stimuli, or even different degrees of the sece stimulus, may produce first a certain defree of functional activity and later produce a depression of this function. He cites rorphine as en example of a stimulus which does this. Worphine given in swall doses always produces first an excitation of the body, but later the excitation disappears and deep sleep follows. The effect of the narcotics can be deconetrated on the 

cell as well as on the entire organism. This relation, however, can only be demonstrated by certain kinds of stimuli, for there are those that induce only functional activity, (i.e., pure excitant stimuli) and others that induce only $\varepsilon$ depression of this function, (i.e., pure depressent stimuli).

The entire nature of stimuli, in so far as they affect the nerve cell, way be briefly summed up under three heads: first, those purely excitant: second, trose purely depressant; and third, those which first excite and later depress.

Verworn further demonstrates that those stimuli which consist in an increcse in the factors that under normal conditions act upon the cell, such a increase of the surrounaing temperature, produce first the changes of tunctional activity, and after carrying the increase to a certain point superiupose the changes of depression on this functional activity. He also shows that a diminution of the vital conditions, for example, a decrease in the surrounding temperature, appears in general to depress with increasing intensity the vital phenomena without previous excltation. This work has been confjrmed 

Prow the anatomical side by the later work of Dolley and his associates.

That there are definite enatomical chanpes produced in the nerve cell wrich corresnond to the physiolopical condition of the cell, appears deanstrated. But owing to the fact that the classification of the exact anatomical changes noted in the nerve cell, as used in the interpretation of the changes noted in the caterial examined by the writer, is of recent origin, a more extended description of this classification will be given. For this purpose the anatomical chenges due to functional activity will be first considered.

The process of exhaustion of the nerve cell from functional activity has been divided into numerous intermediate stages. It is based on the evidence of many investigators. There is no break in the continuity of the process of ectivity and the structural evidences of transition from stage to stage are distinet and definite. Also the orderly shifts in the chromatin distribution in the cell, from an excessive aw ount to a very much lessened amount, simplifies this classification. Excluding the more theoretical arguments for the classification of changes into 

strges, and relying solely on the norphological and empirical basis, supported by the investigation and the analysis of the consensus of opinoin, the changes would fall most satisfactorily in the same definite. eonstant, and orderly sequence.

The present classification, which has been divided into thirteen stages, is based fundamentally on the shift of chromatin in the cell and the size change in the cell. Briefly stated, in terms of the chromatin distribution, the thirteen stages are as follows (Dolley, 1910):

"1. The resting cell.--It is lacking in intranuclear chromatin except within the karyosome (nucleolus) and the amount of extra-nuclear chromatin varies with the individual.

2. The stages of progressive hyperchromatism, in vich, in the pure type, the initial enlargement of the whole cell resches its maximum.

3. The stage of maximum hyperchrowatism, which is associated with the beginning of shrinkage,

4 and 5. The stages of regressive hyperchromatism together with the maximum of shrinkage. Coincident in place but separated originally to denote difference in shape, Stage 4 being more attenuated and spindle. 

Both stages 4 and 5 are to be further divided into. an early, the pure Hodge type, and a late division, characterized $b_{y}$ the sharp beginning of nuclear edema.

6. The return of the cytoplasmic chromatin in its continued reduction to the average normal level. This stage is principally distinguished morphologically by the maximum disproportion in the size of the nucleus owing to its much preater edema.

7 and 8 . The steges leading to the primary disappearance of the cytoplasmic chromatin.

9 and 10. The stages of secondary restoration of cytoplasmic chromatin. The chromatin is first piled about the neclear membrane and then passes out.

11. The stage of secondary disappearance of cytoplasmic chromatin. With the complete using up of the nervous supply, the karyosome is lett containing only a vestige of basic chromatin in a much more exhausted looking cell.

12. Ine disintegretjon and passing out ot the ultimate contents contained within the karyosome. 13. The exhausted cell.

The interpretation of these stages has been made in terms of Hertwig's nucleus-plasma relation theory 

and his theory as to the orifin of the chromatin, which is closely dependant. This nucleus-plasma theory, briefly stated, is that for every cell there is a certein definite volumetric relation between the nuclear mass and the cell mass. So far as this relation is effected by function there are metabolic increases or decreases in size of both elements. He explains chromatin formation specifically in terme of this theory. This conception, as applied to the nerve cell, is that the so-called Nissl substance,that is, extranuclear chromatin, is obtained through the ectivity of the nucleus. First the cytoplasm must absorb certain materials from its surroundings, the blood and lymph, and prepare this material for the nucleus. After this is accowplished the material is baken into ${ }_{\Lambda}^{\text {the }}$ nucleus, where it is sjnthesized into chrowatin, or chromatin-yielding substance. This chromatin ruhrtance is then resorbed by the cytoplasm and is trus stored for quick use by the cell during activitj.

Based upon this idea, the whole process way be simply separated into three wain dirisions. First the stage of hyperchromatism results from the stimulus 

to work. The hyperchromatism declines due to the process of metabolisw being slower than the cell demands unòer continuous stiulation. The second divisjon is the attempt of the nucleus to compensate and to supply the cytoplasm with further material. Ohis necessitates a relinquishing of some of the reserve material of the nucleus, which while it serves to supply a temporary dewand for more chromatin, eventually weakens the nucleus so that the metabolic process is still slower. After this supnly of chromatin is ured up, the nucleur makes its third and last attempt to furnish material by giving out the chromatin wich it holas in its karyosome. This third suppl. of chrowatin, after being used up, leaves the cell exhausted; its supply of nuclear cinociatin used up, its nucleus markedily weakened and the entire cell incapacitated for further functioning.

Again in terms of Hertwig's nucleus-plasma relation theory, the progressive enlargement of the cell in the stage of hypochromatism, is necessarily á purposeful one. With an undiwished ảemand for chrowatin during functional activity of the cell. 

the cell body is forced to take in an increaced anount of materigl from the outride, and the nucleus, in turn, is forced to take in more prochrocetin from the cytoplasa. This enlargewent of the cell. furnishes a valuable index as to the stage of activity of a cell at any given tiwe. Brietly summerized, the factors upon which the anatomical diagnosis of conditions of functional activity are based are: first, the shift in the awount of chrometin within the cell from hjperchromatisu to pypochrowatisa and on to complete loss of chromatin in exhaustion; second, the shift in the nucleus-plasma relation. In the hyperchromatic stages this is essentially a shift in favor of the nucleus; later hovever, the shift is in favor of the cytoplasm and remains so until exhaustion. The process of depression of function is a very diff anatomical condition. Depression of function, as the name implies, is merely a stoppage of the physiological function of the cell at any stage of its activity. In a study of the nerve cells of any animal in depression one is able not only to find depression of the resting cells but also to find 

and dianose depresced cells of the various stages of activity. For the sake of brevity the anatomical changes of depression for the stares of activity will not receive individual attention but the more general effects upo. the cells will be noted.

The funawental difference between a cell in a certain stage of functional activity and the same cell in depression is that in the latter the nucleus is found to contain varying amounts of chrometin, corresnonding to the degree of depression, while the cytoplasm is deficjent in chrocatin to a corresponding aegree. In the resting cell, which norwally shows an abundance of extranuclear chrowatin, this extranuclear deficiency varies from an appreciable lessening in acount to an absolute disappegrance. The same is also true for the hyperchromatic cells, which normally have an excess abount of extranuclear chromatin. Sharply defined grenules gradually becowe less distinct ond the acid staining elements of the cytoplasm becowe more distinct, until finally the cytoplasm takes the acid stain sharply and there is little or no basic staining substances left. In the interweciate stages, just before the final loss of basic staining substance, the stained cytoplasm 

may appear aurky, turbulent, or floccular, or the rewining basi-chromatin may appear as fine dustlike particles.

The same changes noted in the hyperchromatic cells are also noted in the hypo-chromatic cells, but owing to their normally lessened amount of chromatin, it may not be so obvious. The marked edema present in the more advanced stages of hyperchromatism also changes the appearance of the cytoplasm from a deep acid staining, hyaline mass to a much lifhter staining and more broken up mass. The chances in the nucleus deserve a brief consideration too, since these changes are no less marked than those apparent in the cytoplasm. In the early stages of depression of function, the nucleus-plasma relation is disturbed in favor of the nucleus. With the nuclear enlargement, there is associated a progressively greater deposition of the chromatin within the nucleus. This increase of the intranuclear chromatin in cepression is most characteristic, since for the most part the normal nucleus contains no basic chromatin except in the karyosome. I The deposition of the chromatin may be in the form of well defined granules or it may be 

in a more fluid form, giving the nucleus a more homogeneous basic staining appearance. The karyorome mey be duplicated by the appearance of like bodies until in the more advanced stages many such bodies may be presant. In the last stapes: i.e., those approaching exhaustion, Laryorrhexis, or a dissolution of the karyosome may appear, leaving the true, acid staining, nucleolus. The ${ }^{0}$ of the entire nucleus, at the time of complete depression of function, is one of a homogeneous, formless mass, taking predominantly the basic stain as opposed to a more granular, mesh-like and acid staining appearance in the cytoplasm.

By the aid of special stains ano methods, Dolley (1913) has proved that associated with profound aepression there appears in the cytoplas. a denosition of yolk material, and also in special cases a deposition of glycoren. The yolk material was noted as appearing not only in distinct globules but also in more diffused form, fiving the cytoplasm an opacity not unlive one resulting from icuproper technic of fixation or imbedding. This deposition of yolk material in depression has been demonstrated 

to occur in the sex cells and other body cells. It has a marked significance, since it dewonstrates the fact that the cytoplasm is incapacitated for work to such a marked aegree that the raw material taken in is not synthesized into prochromatin, but deposited in the cytoplasm unchanged. The same significance is also attached to the denosition of elycogen in the cytoplasm. The results of tests for giycogen absorbtion in the normal nerve cell have for the nost part. been negative, thourh it aoes occur to excess in depression. This abcorption of glycogen only in depression may be due to come chewical change in the cytoplasm, but this has not been shown as yet. Briefly, then, to summarize the changes occurring in the nerve cells due to the depression of function, they are:

a). A lescenine in the amount of chromatin in the cytoplasm and on increase in the abount of chromatin within the nucleus, which signifies a shift in the nucleus-plasm relation in favor of the nucleus.

b). A deposition of yolk meterial in excessive amounts in the cytoplasm. 

c). A deposition of glycomen.

d). At its maximum, a breaking up of the chromatin of the nucleus into a homogeneous mass, together with karyorrhexis. The process here becomes a process of àeceneration.

On the basis of such distinct differences in the changes of activity and depression, the functional state of the animals was diagnosed after subjection to the different bacterial toxins. Differential counts were made, both of the nornal aniwals and of those cubjected to the toxine snd by cownerison the degrees of sctivity end depression, either sinfly or together, we átonstrated. 



\section{SOURCE OF MATERIAL.}

The rabbit was used almost exclusively in this series of experimente. Only healthy adult animals were used. So far as could be determined they were all exposed to the same physical conditions and given the same care after inoculation. When an anesthetic was necossary for the inoculation, etner was used. The anjels vere killea wiin ether.

In order to obtain the approximate normal for rabbits under these conditions a series of six undisturbed anikals was first killed by ether and the cerebellum recovered and imwediately placed in the fixing fluid. The tissues from these normel animals was ctudied enc drawings of the various steges of activity made in order to furnish a permanent gaide for the differential count. Differential counts were made from three of the normal animals for comparison with the counts made from the animals treated with the becterigl toxins (Table I ).

The next group of animals was given hypodermic injections of a bouillon culture of staphylococcus aureus. Of the two animals treated with this 

bacterium, one(Exper. 2. Staph.) developed an immunity and the injections were stopped after the twenty-ninth day.

Experiment I, Staphylococcus Group.-Bouillon cultures of Staph. aureus used. Adult male rabbit. There were eight injections given over a period of twenty-nine days. The amounts of the culture varied from $\frac{1}{2} \mathrm{cc}$. of a very old culture, to 5 to $10 \mathrm{cc}$ of a very fresh culture. The injections vere made subcutanesusly into the tissues of the back, shoulders, and axilla. The recognizable symptoms began with a slight tenderness and swelling at the site of the injection and progressed to the impairment of respiration and digestion. Just before death the animal became very weak. The animal died on the twenty-ninth day and the materiel was ecured within an hour.

The third animal studied in this group was one which suffered a spontaneous infection of a mixed staph ${ }^{4}$ ococcus type.

Experiment III, Staphylacaccus Group.-Adult female rabbit. The aniwal was very much 

emaciated when discovered and the physical signs indicated an infection. The character of this infection was not ascertained until after the animal was killed. The animal was only under observation fourteen days although it is very probable that the infection dated back of this time at least two weeks. The animal was killed with ether, owing to its critical condition, and an autopsy immediately performed. The physical examination revealed no lesion nor any sign of injury. The examination of the viscera revealed only a congestion of the lungs and a white purulent exudate in the nagal cavities. The bacteriological findings were:

Lungs--.....-.-.-. Staph. albus \& B.coli.

Brain Pluid--.----Staph citrius.

Peritoneal fluid-----Staph. albus.

Pleural fluid------Nothing.

Pus from nose------Staph.aureus, albus, and citrius

Heart blood-.-.-----Staph.albus and citrius.

A third group of animals was given a toxic dose of diptheria toxin. Only the material from two animals was studied and counted. 

Experiment I, Diputheria Group.--

This animal was given a subcutaneous injection of a lethal dose of a standard diptherial toxin. The animal developed paralytic symptoms about the end of the first week and was killed with ether and the brain excised. Experiment II, Dip ptheria Group.-This animal was treated as in Exp. I. The paralytic symptoms appeared about the end of the first week and the animel died about the second day after. The brain was immediately taken and fixed.

The last group of aniwals was inoculated with a fixed virus of rabies. Two different viruses were used, one obtained from Parke Davis \& Company and the other from the Malford Company. It was found that these viruses were fatal on the seventh to the ninth day. Experiment III, Rabies Group.--Adult male rabbit. Dose $\frac{1}{2}$ cc. of the emulsion. The injection was made subdurally thru the sphenoidal fissures of the right orital cavity. The animal appeared slightly nervous and did not eat readily, on the fifth day after inoculation. It was killed on the fifth day. 



\author{
Experiment IV, Rabies Group.-- \\ Adult male rabbit. Doce and method of inocu- \\ lation as in Exp. III. Very minor symptoms \\ appeared on the fifth day and on the sixth \\ the animal seemed to be in the early stages \\ of paralysis. Killed on the sixth ary. \\ Experiment VII, Rabies Group.--
}

Two animals. Adult male rabbits. Dose and

method of inoculation same as in Exp. III.

These aniwals showed paralysis on the sixth

day and were profoundy paralyzed during the

last two and a half days. Both animals died

on the ninth day.

Other aniwals were studied at different times during

the course of the intoxication from the bacterial

toxins as controls for the animals listed. There

were no complete differential counts made on these

animals and so they are not listed here. 



\section{HICEOSCOPIC TECHUIC .}

Following the experimental work of Mann (1894). Fleming (1895), v. Ienhossek (1897) and the adopted custom of this laboratory, corrosive sublimate was used constantly for the fixation of brain tissue. Dolley (1911) compared the results obtained from the more common types of fixatives and proved that the findings in the nerve cells are constant no matter what the fixative employed. Undue distortion of shape is so strikingly absent after sublimate fixation, that in view of the fact that so much depends upon that feature in the anatomical diagnosis of nerve cell ectivity, it is immeasurably superior to the other fixatives commonly employed, particularly strong alcohol. The aqueous subli.ute was combined with formalin according to the following formula:

Saturated corrosive sublimate - 40\% Formaldehyde-- 5 c. After fixation the tissue was run through the graded alcohols up to $80 \%$ and then iodized six hours. After being run through alcohol, alcohol- 

xylol, xylol, and xylol-paraffin solutions, the blocks were imbedded in parafin and routine sections cut at five micra thickness. The sections were mounted by the water method.

Following the wotk of the investigators above, the sections have been stained in toluidin blue. Erythrosin has been employed as a counterstain in the solution recommended by Held, (i.e., one gram to one hundred and fifty cubic centimeters of distilled water, to which are added two drops of strong acetic acid).

The technic is very simple. After removing the paraffin with $x y l o l$ the sections are passed through graded alcohols to water. They are then stained one or two minutes (usually one and one-half minutes is sufficient) in the erytrosin solution warwed to $40^{\circ} \mathrm{C}$. After thoroughly washing in water, they are stained in the toluidin blue solution for about seven minutes, again washed and then differentiated in ninety five per cent alcohol. For this purpose the sections are run rapidiy through fifty, seventy, and eighty per cent alcohols and then passed to the ninety five per cent in which they are allowed to 

remain until sutficiently differentiated. The process of differentiation is followed under the low power and stopped when the internal warkings of the cell are clear. The condition of the cells in the granular layer offers a valuable index as to the exact amount of decolorization. After placing the sections in absolute clcohol for a few minutes the $\because$ are cleared in $x_{y}{ }^{\circ} I_{\Lambda}$ mounted in Canada balsam. "his wicrosconic technic has been presented in some detail to ennhasize the fact that the results obtained in tris study have been atteined through the use ot the ordinary cyt) (ological methods and there has been no occasion to resort to more unusual or Ireakish stains. 



\section{ANATOMICAL AIID PHYSIOLOGICAL ANALYSIS \\ OF THE MATERIAI.}

As a basis for the analysis of the anatomical changes in the nerve cell due to the effect of the bacterial toxins used, it was felt necessary to eliminate, as far as possible, errors of observation aue to an impertect study or due to preconceived ideas as to what conditions should be expected. For this reason the basis of analysis is the differential counting of the cells as given in the accompanying Tables I, II, III, and IV. This method is valuable in that it affords definite and concrete figures, although these figures are in a measure approximate, partly due to technical difficulties, partly due to the difficulty of separating a continuous process into definite and fixed stages, and partly due to the variations in aifferent areas of the material. Althourh the variations in different areas of the material vere not great, it was an abcolute rule that heginning at a definite starting point, each consecutive cell was classified either under the definite stages of activity or depression, or both, or undor the more general classes of 

hyperchromatism or hypochromatism if not fully identified. Since the tables present a detailed comparison of the results obtained from the differential count, only the general deductions of importance will receive consideration at this point.

For the most part, only the changes of activity and depression are to be seen in the material obtained from the experiments. While there are a certain number of small cells found in recovery and a smaller number of frantly senile cell present. absent they were so conspicuously in the majority of cases that a close tabulation of them was not deemed necescary. In any procers of activity or depression where the stimulating factor is continuous, as in this toxic stimulation, the time is not afforded the cell for recuperation which is necessary in order to produce frankly senile cells or true types of recovery cells.

It is important, both for the sake of comparison and from the physiological side, to note that only one cell was seen in all of the material studied from normal resting animals which could be diagnosed as a cell in depression. This vas a cell in the first stage of hypochromatism (See table I). By far 

the larger per cent of the cells counted were found to be of the hyperchromatic type, demonstrating the fact that under normal conditions in the undisturbed animal, the nerve cells are but mildy stimulated to function. A graphic representation of the cell count from these normal animals would show an abrupt rise from Stage 1, a maximum at stage 5 , a rapid drop to Stage 7 and then a more gradual decline to Stage 13 or final exhaustion.

Staphylococcus Series.-- By comparing the results obtained from the animals receiving the staphylococcus infection with the normal, it will be readily seen that the toxin has a stimulating effect upon the nerve cells. (Table II). This simulation, while primarily one producing functional activity, acts finally as one producing depression of this activity. In the animal killed before final fatal intoxication from the toxin, (Exper.III, Staph), there was no evidence of depression, but the material showed marked activity since the larger number of cells were found to be in the more advanced stages of hypochromatism. It is also very important to note that there are relatively so many cells in 

complete exhaustion as compared with the normal that it cannot be doubted that the toxin from staphrococcus rroup of becteria produce primarily an increased activity on the part of the nerve cells. Frow the cells in the fatal intoxication from the staphecoccus toxin (Exper. I, Staph.) we are able to diagnose an intense stiulation. The cells not only show wore advanced activity but also a depression of this activity. This is markedly present in approximately half of the cells xunted. Of these depressed cells it is also inportant to note that they show advanced activity with the superimposed depression. From a physiological side, it will be readily appreciated that primarily the metabolism of the cell is not ixpaired but merely perorming its physiological function in a wore strenuous manner. Finally this exceeds normal limits either from causes belonging to the nature of bacterial toxins or because the poisonous by-products evolved are too great and the cells are thrown into depression of function. Diptheria series.--The wost salient feature brought out by the differential count on the animals injected with the eiphtheria toxin (Exper I \& II. Diphth. Group) is that in anjuals reaching the 

paralytic stage all, or nearly all, of the cells are found to be in a state of profound depression (Table III). The cells in the animal dying from the intoxication (Exper. II) showed a more profound exhaustion from functional activity and also a more profound depression than the animal killed earlier. This toxin cannot be interpreted as one producing only depression of function since by comparison of the counts from either of the inffoculated animals with the normal it is evident that there is advanced activity present as well as the superimposed depression. This anatomical findinf is significant of a very important physiological change in the cell. Certainly cells in such advanced sctivity with such profound depression superimposed are in no condition for effective function. While the number of experiments performed with this toxin is not sufficient to make definite statements, the evidence seems to indicate that the phenomenon of paralysis may be closely dependant upon the functional. stete of the cell; so closely, in fact, that the paralysis of advanced diphtheria may be considered as a sequel to the profound depression of the nerve cells. 

Rabies Series.-- The differential counts made upon the animals suffering from rabies were demonstrative of the most marked changes noted in any of the material examined in these experiments. The count was only possible in the earliest of the aniwals since in both of the animals dying later the changes were of a degenerative character. In the animal which was killed after the fifth day (Exper. V, Rabies), about one half of the cells were found to present only activity while the remainder showed superimposed depression (Table IV). It is important to note that he activity was distinctly farther advanced than in the normal enimels. This fact. while significant of an active stimulating factor, is most important from a physiolorical point of view. The animal was demonstrating no outward signs of the rabie intoxication until a few hours before it was killed, when it became sliphtly nervous and did not eat readily. It would be expected in an animal giving a mild clinical picture that the changes in the cells thenselves would be of a mild type, provided that the physical symptoms are the outward conifestation of the physiological state of the cells. 

This conaition is denonstrated by the differential counts of the first animal. The more advanced degeneration in the animal killed on the sixtin aay tokether witn the clinical synptoms of paralysis further bears out this hypothesis.

In the six day aniwal (Exper VI. Rabies) while there is actual degeneration of the nerve cells of the cerebellum, this process has not been carried to such an extent as to cause the utter disappearance of the cells. This degeneration which is coinciaent with the onset of the paralysis ceems to stand in causal relation to this peralyois. A nerve cell showing functional activity or furctional depression, short of exhaustion, is cepable of still further function (i. e., irritability and conauction of nervous impulsesl. Degeneration must mean absolute depression. Therefore in the five day animal, in which none of the cells were found to be in actual degeneration, there were present np physical symptoms of paralysis or loss of organic function. When a cell has once gone beyond the limits of depression proper to degeneration, there is a total loss of functional power and the outward symptoms of paralysis are manifested. 

The anial aying on the ninth day Exper. IX. Rabies) showed degeneration of the cells which were recognizable, though, for the most part, the cells had disappeared. Paraljsis began on the sixth day and was almost coninlete until the death of the animal on the ninth day. With the undininished production of the toxic waterial, the cells are carried from depression to actual aegeneration, and then to final total destruction.

The finding of profound functional depression coincident with the symptoms of paralysis, in the animgls treated with the diphtheria toxin, is in accord with the observations made upon the aniwals suffering from rabies intorication. However, the physiological process present in the diphtherio material was not so far advanced, since the cells were not definitely in a state of degeneration.

A profound depression merges into degeneration, if the process continues, as the rabies material shows, but so far it has been impossible to determine the actual point of transition. Practically the diphtheria material was very close to defeneration. Both in rabies and in diphtheria, the paralysis appears to be either an outward nanifestation of de- 

generation of the nerve cell resulting from profound depression or a result of the most profound depression unconplicated by degeneration. The intensity of the outward effect would likely differ but slightly in either case though the damage woula be more permanent after actual degeneration and necrobiosis, especially if it ends in complete necrosis. 

Table No.. I.

Normal Rabbits..

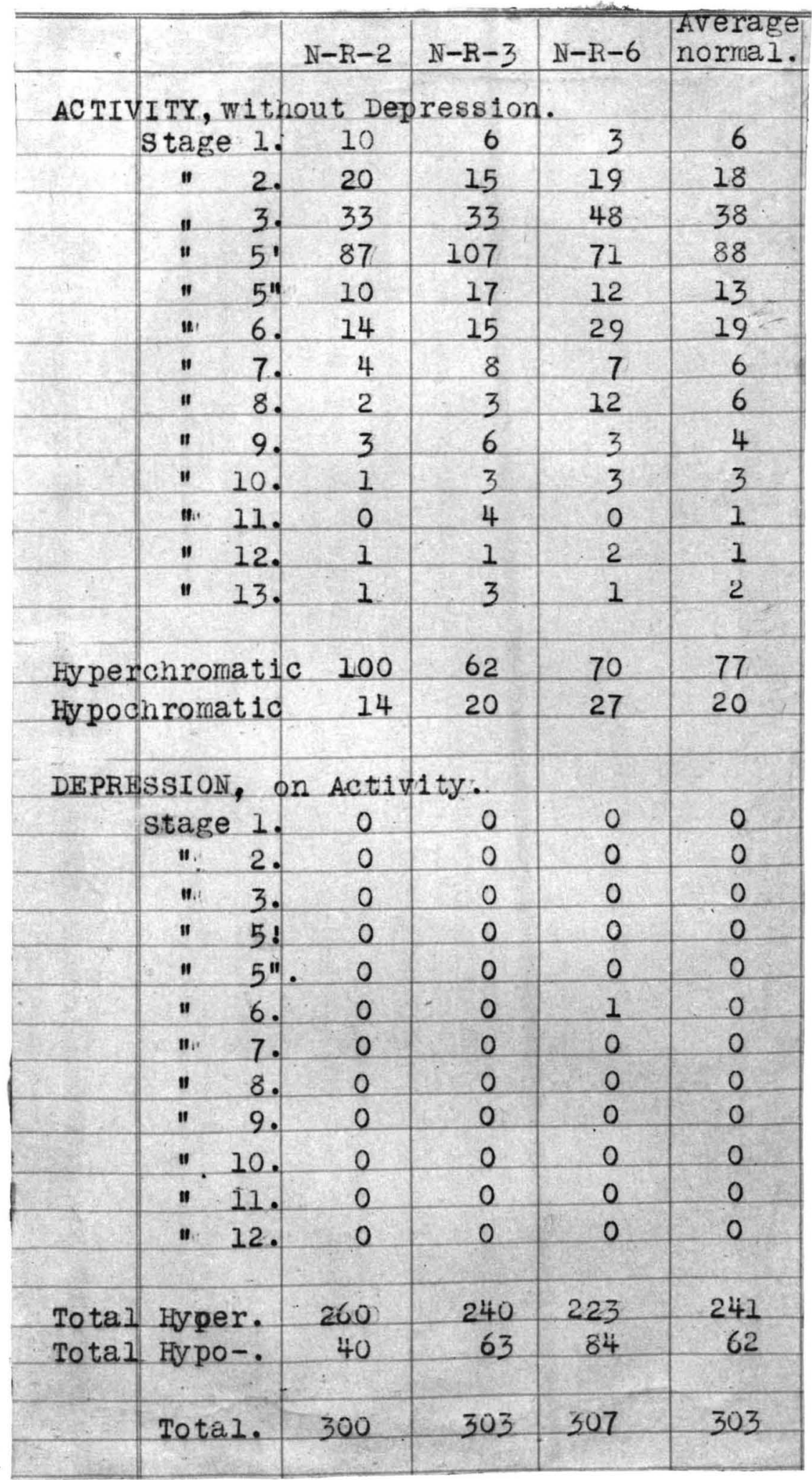



Table No.. II.

Mixed Staph. \& Staph. Aureus.

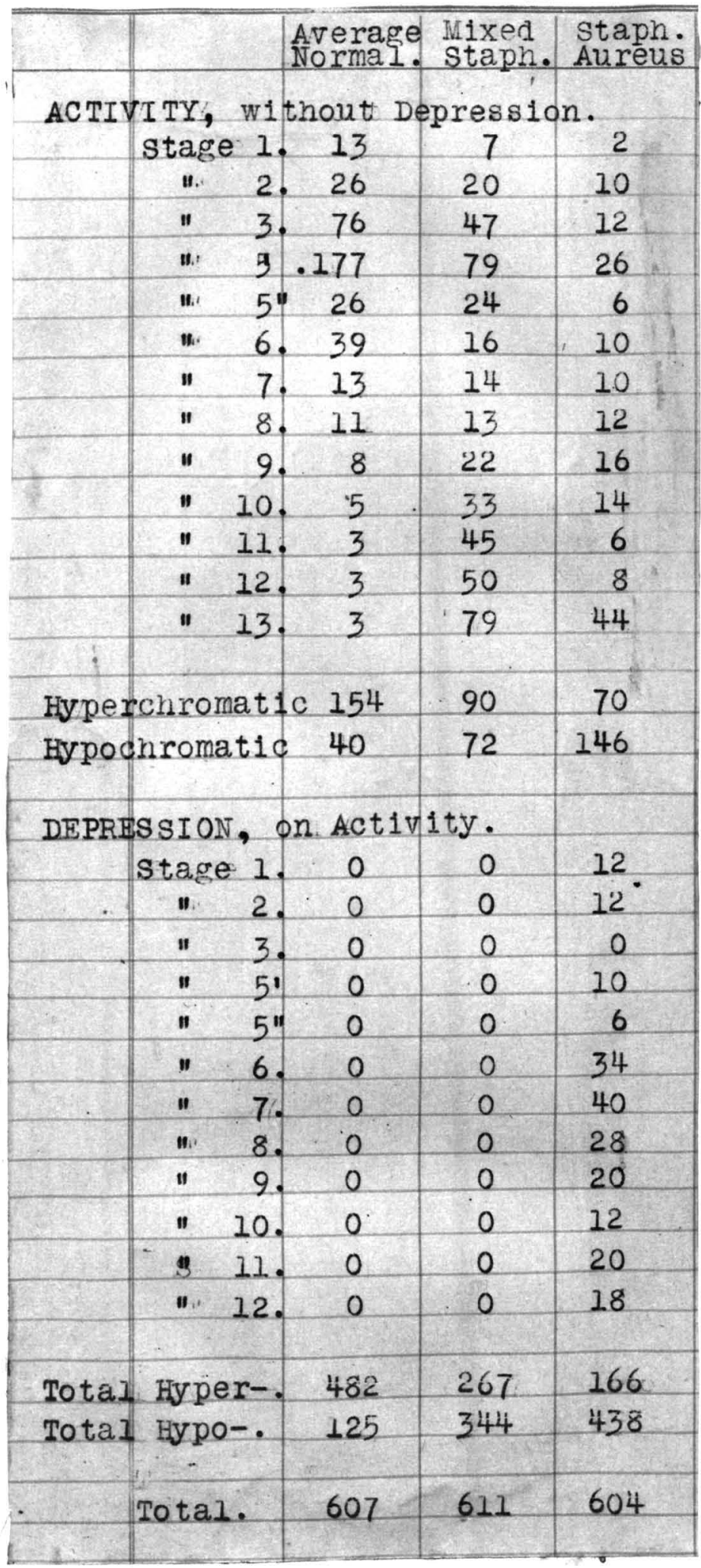



Table No. III.

Diphtheria.

\begin{tabular}{|c|c|c|c|c|}
\hline & 68 & $\begin{array}{l}\text { Average } \\
\text { Normal. }\end{array}$ & $\begin{array}{l}\text { Diph. } \\
\text { R-1. }\end{array}$ & $\begin{array}{l}\text { Diph. } \\
\text { R-2. }\end{array}$ \\
\hline \multirow[t]{14}{*}{ ACTIV } & VITY, W1 & thout DE & epress 1 & on. \\
\hline & stage 1 & . 6 & 0 & 0 \\
\hline & 11. 2 & 18 & 0 & 2 \\
\hline & 113. & 38 & 0 & 0 \\
\hline & 9 & 88 & 0 & 0 \\
\hline & " 5 & 13 & 0 & 0 \\
\hline & 16 & 19 & 0 & 0 \\
\hline & 7. & 6 & 0 & 0 \\
\hline & 18. & 6 & 0 & 0 \\
\hline & ".. $\quad 9$ & 4 & 0 & 0 \\
\hline & n. 10 & 3 & 0 & 0 \\
\hline & " 11. & 1 & 0 & 0 \\
\hline & $1 \quad 12$. & 1 & 0 & 0 \\
\hline & " 13. & 2 & 4 & 17 \\
\hline Hyper & rchromats & 77 & 21 & 20 \\
\hline Hypoc & hromatio & 20 & 46 & 23 \\
\hline \multirow[t]{13}{*}{ DEPR } & ESSION, & \multicolumn{2}{|c|}{ on Activity. } & \\
\hline & Stage 1 & 0 & 14 & 7 \\
\hline & " 2 & 0 & 19 & 14 \\
\hline & 113 & 0 & 14 & 23 \\
\hline & 11. $\quad 5$ & 0 & 18 & 25 \\
\hline & 115 & 0 & 3 & 6 \\
\hline & 116 & 1 & 32 & 34 \\
\hline & " & 0 & 64 & 38 \\
\hline & W. 8 & 0 & 34 & 23 \\
\hline & 119 & 0 & 17 & 21 \\
\hline & - 10 & 0 & 10 & 20 \\
\hline & *. 11 & 0 & 3 & 13 \\
\hline & " 12 & 0 & 3 & 16 \\
\hline Total & Hyper- & 241 & 89 & 97 \\
\hline Tota1 & Hypo-. & 62 & 213 & 205 \\
\hline & Total. & 303 & 302 & 302 \\
\hline
\end{tabular}



Table No. IV.

RABILS.

\begin{tabular}{|c|c|c|c|c|c|}
\hline & & \multicolumn{2}{|c|}{$\begin{array}{l}\text { Average } \mathrm{R}-5 \text {. } \\
\text { Normal }\end{array}$} & $R-6$ & $R-9$ \\
\hline \multicolumn{6}{|c|}{ ACTIVITY, without Depression. } \\
\hline & Stage I & . 6 & 0 & & \\
\hline & 2 & 18 & 0 & & \\
\hline & 3 & 38 & 2 & & \\
\hline & 5 & 88 & 10 & & \\
\hline & 5 & 11 13 & 4 & & \\
\hline & 6 & 19 & 6 & & 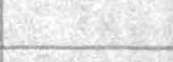 \\
\hline & $7 \quad 7$ & 6 & 10 & & व. \\
\hline & +8 & 6 & 10 & & 离 \\
\hline & $\begin{array}{l}-\quad 9 \\
-\quad 9\end{array}$ & 4 & 12 & $\therefore$ & $\overbrace{\varpi}^{\infty}$ \\
\hline$\therefore$ & 10 & 3 & 16 & $\stackrel{-1}{0}$ & \& \\
\hline- & 11. & 1 & 18 & $\underset{\omega}{\vec{j}}$ & $\mathbb{\pi}_{\infty}$ \\
\hline & 72 & 1 & 20 & क्ष & $\frac{1}{01}$ \\
\hline & +2 & 2 & 26 & ฮี & $\rightarrow$ \\
\hline & & & & $\frac{80}{0}$ & 8 \\
\hline Hyper & ohromati & c 77 & 15 & & $\frac{1}{9}$ \\
\hline \multirow{2}{*}{ Hypoc } & inromatic & 20 & 25 & $\ddot{0}$ & 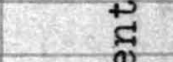 \\
\hline & & & & $\stackrel{0}{ \pm}$ & . \\
\hline \multirow[t]{14}{*}{ DEPRE } & SSION, 0 & n Activ & ity. & $\underset{\varpi}{\varpi}$ & $\stackrel{4}{\pi}$ \\
\hline & Stage 1 & 0 & 0 & 02 & $\pi_{1}$ \\
\hline & $\begin{array}{r}0 \\
\square \quad 2\end{array}$ & 0 & 2 & ๘ & $\leftrightarrow$ \\
\hline & 3 & 0 & 4 & ॠ & ${ }_{0}^{0}$ \\
\hline & +8 & - 0 & 14 & - & (1) \\
\hline & 5 & an 0 & 4 & సี & $\underset{\ddagger}{\infty}$ \\
\hline & 6 & 1 & 12 & ¿ & \& \\
\hline & 7 & 0 & 10 & ${ }_{10}^{0}$ & o \\
\hline & 8 & 0 & 14 & $\infty$ & . \\
\hline & 9 & 0 & 14 & 7 & 8 \\
\hline & 10 & 0 & 16 & 0 & 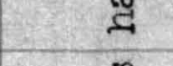 \\
\hline & -11 & 0 & 18 & & $a$ \\
\hline & 12 & 0 & 18 & & 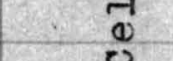 \\
\hline & $5 \times$ & 8 & & & \\
\hline Total & fyper-. & 241 & 55 & & \\
\hline \multirow[t]{3}{*}{ Total } & Hypo-. & 62 & 245 & & \\
\hline & Total. & 303 & 300 & & \\
\hline & & & & & \\
\hline
\end{tabular}





\section{REVIEW OF LITEFATURE.}

In the review of the papers by other investipators on the cytological changes in the nerve cells due to the effect of bacterial toxins, only those will be considered by the writer which are due to the bacterial toxins discussed in this paper. There will be an attampt made to correlate the findings of these investigatore with those found in the present ciaterial and so far as possible to interpret their objective descriptions in the light of the wore recent classification of activity and depression. This interpretation will be made in order to show that their findings were not at variance with those recorded in this paper.

So far as the writer has been able to ascertain, there have been no recorded observations upon the effect of the toxins of the staph bacteria on the nerve cells.

There has been considerable investigation of the effect of the toxin of $B$. Diphtheriae on the nervous system, especially after the disease has reached the paralytic stage. Rainy (1900) re- 

viewed the literature very completely up to that time, which has simplified the writer's task. Apperently fainey's work concludes the original investigation previous to the present one.

The first work of the neurocytological siae of diphtheria was reported by Charcot and Vulpian (1862). They discribe some changes in the fibers of the palatine nerve, but do not note the changes in the cells. Weber (1864) reported two post-diphtheritio cases in which he reports that there was no changes present in the nerve cells. The probable explanation for the nonobservance of the changes in the nerve cells by these early writers is that their microscopic apparatus or technic was inadequate or their recognition of these changes imperfect.

Clos (1868) describes changes in the nerve cells in a case of diphtheria which he says are comparable to those changes produced by the sectioning of a nerve axone. It has been proven by 1. D. Davis, working in this laboratory, that the effect upon the nerve cell of sectioning the axone is one of depression primarily. (Thesis 1914). Then Clos must assuredly have seen cells in depression in his material. 

Oertel (1871) observed a condition which he describes as infiltration of nuclei and growth of eranulation tissue in the anterior cornua of the spinal cord. In this paper he records no changes in the nerve cells themselves. Oertel (1874) writing in the Cyclopaedia of the Practice of Medicine, says that there is degeneration of the brain tissues and cells in the region of small blood clots which he obcerved formed in the brain. This point vas not confirmed in the material examined by the writer, but it is very probable that if such clots were present that the cells might be ...re affected in the $t$ area.

Vulpian (1876), in two or three cases, observed modifications in the anterior horn cells of the spinal cord, whith he describes as being more globular than usual. He also noted that their content was unusually homogenous and that it almost concealed the nucleus. These results are essentially like the ones that the vriter has observed in the present material. The cells in advanced activity are always larger and readily appear swollen, while the cell showing depression often shows a diffuse aistribution 

of chromatin especially spreading over the nucleus. Dejerine (1878) published a raper in which re describes the nerve cells, especially those of the spinal cord, as becoming rlobular, as being d ficient in processes, and as possessing very indistinct nuclei and nucleoli. To some extent, the nerve cells were entirely deficient. Dejerine's description is very much like that made by Vulpian and the same interpretation will hold in this case. The material examined by the writer appeared to be d ficient in the nerve cells in certain areas but as no quantitative analysis was made this point can not be definitely stated.

Quinquand (1880) confirmed the work of Dejerine, reporting the finding of many cells affected, especially those in the lumbar region of the spinal cord.

Meyer (1881) describes some of the cells of the spinal cord as being swollen, granular and to some extent degenerated. The swollen cells were more than likely cells in late activity, while those showing granulation and degeneration were certainly depressed.

Kidd (1883) reported the finting of some of the cel 1s of the spinal cord in a condition of atrophy. 

This findin was possibly due to the senility of the cells under observation. Dolley (1911) proves that the characteristic finding in senility is the markedly shrunken appearance of the cells. Mendel (1885) reported the absence of cellular changes in the cells of the brain and spinal cord of a child dead from diphtheric paralysis. Bristowe (1888) also found no changes apparent in the nerve cells of a patient dying from diphtheric paralysis. It must be remembered that this period represents a very early stage in the development of neuro-cytology. NissI's substance had not yet been seen. Following these two negative reports Eustace Smith (1889), and Gowers (1892) both gave credence to the finding of definite changes in the nerve cells in diphtheric patients. The former in his book on Disseases of Children notes that the nerve cells are probably affected, either primarily or later in the disease. Govers in the second edition of his Diseases of the Nervous System, says in one rlace, "Diphtheria may cause acute changes in the nerve cells and the nerve roots," and in another place, "Diphtheric paralysis is not wholly peripheral." 

Preisz (1892) recorded the finding of atrophied cells in the spinal cord, in a review of two cases of diphtheric paralysis.

Enriquez and Hallion (1894) noted the dostruction of the cells of the anterior cornua of the spinal cord following diphtheric paralysis. This entire destruction of the cells, according to our conception, is the final stage of depression.

Pernici and Scagliosi (1896) reported the results of an examination of the central nervous system of a diphtheric patient. In the brain many of the cells were normal; othere were somewhat markedly involved, and by Golgi's method were found to present varicose atrophy. The changes in the cord were indefinite, though many of the cells appeared smaller than normal and their protoplasm was granular. The nuclei are reported as hawing often presented a shrunken appearance, while some of the cells were in a state of extremely advanced disintegration. This description is one that applies in the main to cells in depression. The condition described as aricose atrophy refersto nodular shrinking of the process of the cell. Iis observation of cells in extremely advanced dis- 

intecration is quite sicnificant since in the material examined by the writer many of the cells were found to be in complete degeneration from depression and not a few had gone to disintegration.

Crocq (1896) summed up the results of his investigation in a short monograph on diphtheric paralysis. His conclusions will be given at some length as they represent the general state of opinion in the year in which his work was published. He says: "In the spinal cord the diphtheric poison provokes very marked alterations in the grey matter; the cells become swollen, they stain badly, their nuclei and processes disappear; the neuroglia and ependyma proliferate, the nerve cells atrophy or may disappear altogether and be replaced by sclerosed tissue. The white substance is rarely affected. Thus, myelitis generally progreoses slowly. In some cases, however, it miay be rapidly evolved and may end in softening.-.......-With regards to the medulla, the diphtheric poison only produces some swelling of the cells at the lower part---the midale and upper parts remain almost normal. The cranial nerves are not affected by the diphtheric poison. The poison produces in the rabit 

a primary myelitis and secondary neuritis". He also says that the poison produces degeneration and irregularity of the contour of the nerves. This description arplies nicely to the material studied, and as far as the objective description is concerned, it is very accurate. The material studied by Crocq was quite evidently in depression, but it should be interpreted as being in an advanced state of activity before this depression was superimposed. Katz (1897) examined the spinal cord of three children dead from diphtheric paralysis. In all three of them he found some of the cells of the spinal cord partly necrotic and partly exhibiting fatty degeneration. This description belongs to cells in depression since this deposition of fat in the cell is one of the differential characteristics of depression. The observation of degeneration is also a correct one since we know that the final stage of depression is degeneration and dissolution of the cell.

Murawjeff (1897) made a series of observations on guinea-pigs which died from one to three weeks after an injection of a culture of diphtheria. He states that the first lesion to occur was a change in the nerve cell. He found certain cells in the cord in a state of chromatolysis, with nuclear changes 

and vacuolated. The condition he sneaks of as vacuolation was the marked edema so sheracteristic of the advanced stages of activity while chromatolysis is always associated with deep depression. Trom this description we are lead to believe that the cells observed by durawjeff were in a state of profound depression following advanced activity. This is the status of the cells studied in the present material.

Babes (1898) observed chromatolysis, vacuolation, loss of nucleus and nucleolus, vascular chenges, and increased numbers of round cells in the central nervous tissue which he studied. This description is one of cells in depression which is superimposed on activity. The nuclous never disaprears in normal activity.

Woodhead (1898) examined two cords from experimental animals treated with full doses of diphtheria toxin. In one case he noted ${ }_{\Lambda}^{h}$ romotolysis and vacuolation $0 I^{\prime}$ the cells as distinctly marked, while in the other he noted no deviation from the normal. The absence of changes in the second case is probably due to the fact that they wre not of such a marked 

character and thus escaped observation.

Billington (1889) in his book Diphtheria--Its Nature and Treatment, reviews the observations of Dejerine (1878) and others, but does not discuss the significance of these observations. Dejerine, he says, noted that the affected nerve cells were swollen in some instances, in others shrunken, were indistinct, and $\wedge^{\text {lost their processes, and were globular in shape. }}$ The number of nerve cells in certain parts of the anterior cornua of the spinal cord weatly diminished He also states that Gaucher (1881), Abercrombie (1881) in a review of seven cases of diphtheric paralysis, and Percy Kidd (1885) in one case of his own nd ore case of Dr. Mott of Iiverpool, each noted the same changes in the nerve cells that had been noted by Dejerine at an earlier time. The separate phases of this objective description have been discussed in connection with the observations of other writers and it will suffice here to say that this description is also of cells in depression. However, the aescription is different from the preceding ones in the fact that Billington notes the changes in the earlier stages of activity since he includes in his 

description a note about the shrunken hyperchromatic cell (Holee tipe), which is a phenomenon of early activity.

Reiny (1900) reviewed the concensus of opinion up to that time and addei a considerable amount of information to this by a series of animal experiments. Fis work will be quoted at some length as it is of great importance and perhaps the most comprehensive up to this time. His work is based for the most part on experiments on rabbits. He found that animals receiving large doses of the diphtheric toxin and living until the incidence of paralysis showed "a slight

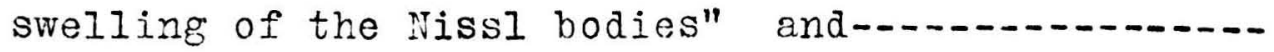
"a fading of the chronatic substance". In another part of the paper re states that in rabbits receiving subacute maximal intoxication from the administration of the toxin and dying after the paralysis had set in, "some cells were slightly swollen, Missl's bodies presented the appearance of somewhat advanced degeneration, the achromatic substance stained but faintly with exytrosin, the nucleus and nucleolus appeared to be normal and the nuclear membrane which, owing to the disappearance of much of the chromatic substance 

of the cell body was often unusually conspicuous, was not crumpled. Some cells, on the other hand, were altered in a very peculiar manner. They were markedly shrunken. Nissl's bodies were not very much affected at first sight; but, considering the reduced volume of the cells, the amount of chromatic substance which it contained was probably diminished; the achronatic substance took on the stain with unusual intensity, whilst many of the group of cells exhibited vicuolations of the protoplasm in a most marked derree." (p. 447)

This description is almost perfect for cells in depression although Rainy does not apply this name to these changes not attempt any functional interpretation. Eis finding of gross vacuolations of the cells does not coincide with the present findings and since a similar thing has been observed in certain of the material in the present collection which was mott probably due to imperfect technic in dehydration of the tissues, these changes will not be further discussed. Rainy summerized his findings in a concise way and a quotation will be given:

"Diphtheric paralysis is associated not only with changes in the peripheral nerves, out also changes in 

the cells of the cord itself. In my experiments such changes were invariably present after death, when paralysis was observed during life. Of the latter, the cellular changes were most characteristic. They may, however, be associated with vascular ones. The changes are very definite and consist of chromatolysis to a moderate degree, in increased staining capacity of the achromatic substance for acia stains, and vacuolation of the cell protoplasm". (p.450). In every instance, where his tissues varied from the normal, in his record of his experiments, he describes them as showing "chromatolysis". (p.452-454).

This description, bearing all the distinctive features of depression as identified by numerous investigators in all types of cells, certainly cannot be interpreted in any other light than that of depression. His observations make the writer very sure of his findings and also very sure of his diagnosis of depression in the material under observation.

Rainy and Playfair (1900) report that they found vacuolation and early chromatolysis in the examination of the cells in the spinal cord of a patient dying of 

diphtheric paralysis. This was reported as a corroboration of the findings made in the animal work. Rainy states that the results in tris human case were very similar to those found in the rabbit experiments. This, then, must have been a depression too. Gowers (1895) in his book Diseases of the Nervous System, writes, "If the elements of the spinal cord are treated with osmic acid, in the recent state, the motor cells are sometimes found in a state of intense granular and fatty degeneration" -..... "The motor nerve cells of the anterior cornua have been folud altered, either swollen and unduly homogeneous or vitreous in aspect or smaller tran normal and often with shrunken processes". He also quotes from Kidd (1883) as his authority for the findings of extensive vacuolation of the nerve cells. All the points noted by Gowers have received consideration elsewhere as regards their significance in depression.

Northrup (1902) writing in Nothnagel's Encyclopedia of Practical liedicine, says, "In the grey matter of the cord many of the cells of the anterior cornual group 

present tro types of arked alteration. Some were slishti swollen. Iissl's bodies presented the appearance of somerhat advanced disintegration; the achromatic substance stained but fisintly. The nuclei and nucleoli appearea to be normal and the nuclear membrane, which, owing to the disappearance of much of the chromatic substance of the cell body, was often unusually conspicuous, was not crumpled. Some cells were warked $I^{\prime}$ shrunken." A large part of the foregoing quotation was probably taken from the earlier work of Rainy, but at any rate it is essentially the same.

Larlett (1903) In a study of four cases of diphtheric paralysis states that he found cells showing "powdery ehromatolysis", an increased staining capacity in the cytoplasm. for the acid stains, and some cell degeneration. He does not believe that the changes in the nerve are seconary to those in the fiber. As to the priority of these changes, the writer takes the ground that the changes are produced in the cell first since definite changes can be determined in the cells before the onset of the paralysis, and it has not been proved that there are any changes in the fibers 

until after the onset of the paralysis. The description of the cells, as given by Laslett, can only be interpreted in the lient of cells in dopression, for although this description is brief, it is concise enough to assure one of its definiteness. Starr (1909) in his Organic and Functional Nervous Diseases, does not treat the subject of aiphtheric paralysis from the neurocytological side to any great extent, but he points out that Murawjeff (1898) showed that the toxin of diphtheria produced chromatoljais and degeneration in the cell bodies of both motor and sensory neurones. This description while very brief can only be interpreted, in the light of the core recent classification of nerve cell activity, as depression, and the term "degeneration"would call attention to the fact that the cells were in a strte of deep depression.

Martin (1892) a \& 1892 b), Hochhaus (1892). Hasche (1895), Thomas (1898), and Batten (1898) all report negative findings in the material examined by them. Batten while not able to find any changes in the cells in the six cases studied by him, stetes that cellular changes have often been found. He states that it is his opinion that these changes while occas- 

ionally present are not constant $\wedge_{\Lambda}$ that the $y$ have a very slight diagnostic value. The non-observance of cellular changes by these writers, especially those working at an early date, is probably due to the lack of knowledge of cytology, for it is evident that any cell if it possesses a nuclear mass is considered normal by some investigators.

To summarize the consensus of opinion of the investigators on the effect of the diphtheric toxin on nerve cells, with but few exceptions all who have studied these changes from a microscopic point of view have written descriptions that most assuredy belong to cells in a state of profound depression. Their objective descriptions, while varying in the exact wording, are in the main all alike in that they have found the changes of chromatolysis, diffusion of the chromatin, loss of cell substance due to activity, and finally degeneration due to excessive depression. This review of the literature on the subject confirms the interpretation of the present material. 

Rabies.---Observations upon the post-mortem appearance of the nerve cells in rabies dates back to the beginning of the eighteenth century, to the work of Mead (I747) and later in the same century to the work of van Sweiten (1771). They did not find any lesions in the central nervous system which they believed to be characteristic of the disease, but the $y$ noted that the central nervous system was affected and described the gross lesions which they found.

Bollinger (1875) writing in the Cyclopedia of the Practice of Mericine, says that the re are no specific lesions found in the brain or spinal cord of animels or man dying from rabies. He observed no changes in the nerve cells.

Gamaleia (1887) and Schaffer (1899) reported the finding of microscopic areas of softening and necrosis in the spinal cord, which the $y$ believed were characteristic of the diseasen This finding was incidental since they were following the lead of previous investigators and were looking only for waschiar changes.

Even after the important discovery of Pasteur that the virus of hydrophobia was selective for the 

nervous tissue, there was little attention given to the microscopic study of the cord and brain, but investicators were very active in a serach for vascular changes. Dasteur; in his original investigations, made fittle or no reference to the appearance of the cells but confined his description to gross apiearance of the tissue.

The most important of the vascular cha ges present were pointed out by Benedikt (1874), Kolessnikow (1875), Cocits (1877), and Gowers (1877). They described an accumulation of leuccocytes around the blood vessels, particularly in the spinal cord, medulla oblongata, and basal ganglia. Other vascular changes often found were conestion, irregular ailatjons, thromosis, hemorrages, and a swelling of the endothelial cells. Babes (1887), and Schaffer (1889) point out that the accumulation of the leucocytes is not restricted to the neighborhood of the blood vessels but that the are found in the central canal and in the nervous tissue, especially around the cells of the motor eanglia. Babes considered the finding of these perivascular and pericullular focal accumulations of round cells of such importance that he believes, within certain limi- 

tations, their presence is diagnostic of rabies. Together with the hemorrhagic lesions referatle to the blood vessels, virious chenes in the rerve cellis have been described. Schaffer (1889) describes atrorhy, vacuolation, and granular, hyaline, and fibrinous degeneration of the nerve cells associated with deceneration of their processes and hyperplasia of the neuroglia. This description is quite evidently one of cells in depression, since granular degeneration and atrophy are typical of depressed nerve cells and since cells in advanced depression give readily the appearance of a hyaline or fibrinous degeneration.

Confirmatory and additional observations have been made by Babes (1887), Gianturco (1887), Golgi (1894), and by Germano and Capobianco (1895), following the work of schaffer. Golgi, by the use of his silver method of staining nerve cells, has described irritative and regressive changes of the nucleus, characterized by increase and subsequent framentation of the chromatin, with karyolysis, bladder-like swelling, vacuolation and granular degeneration of the cell body, atrophy and loss of processes, and event- 

nally the destruction of the entirecell. This is so clearly a description of cells in depression that it cannot be mistaken. Colgi not only saw and described depression clearly, but he also interpreted the various findings in an orderly sequence that agrees with the conception stated in this paper. The most exhaustive alterations were not ed by Germano and Capobianco, who stated that the larger per cent of the cells of the central nervous system showed marked alteration and by comparison they concluded that a laree number of the cells hed completely disappeared. There observations we made for the wost part on animals duinf from street rabies. By comparison the writer has cose to the same conclusion, namely, that there is a great disappearance of the cells from the cerobellum in the late stages of the dicease. Babes reported the fincing of changes similar to those previously deccribed in a imals dying from street rabies but states that no chances vere produced in the nerve cells of animals inoculated with a fixed virus. This finding is not in accora with the findings of many of the late invertigators, and certainly not with the findings of the writer. 

Ihis, in a brief way, sums up the investigation of the effects of rabies on the nervous system up to the beginning of 1900. Van Gehuchten and Nelis (1900) published several papers treating this subject, which stimulated much more invertigation, so that following the publication of their work there is a considerable amount of literature on the subject. Their work was critically reviewed by Crocq (1900). These writers have called attention to the very early publications of Pollaillon and Nepreu (1872), who in their report describe the accumulation of the round cells around degenerated nerve cells in the Gasserian ganglion. This observetion was made from a human case. Van Gehuchten and Nelis believe that the former findinge were not of a specific character which would assist in the diagnosis of rabies, but that they were werely the products of any inflammatory condition. They note that the nerve cells viere changed in appearance and many of them degenerated. They found peculiar nodules in the cerebro-spinal and sympathetic ganglia which were, so far as their experience went, a constant factor. This vork was confirmed by the investigations of Hebrant (1900), Nocard (1900), ehuille and Valle (1900), and Ravenal and lfecarthy (1900), on experimental animals, and bJ Gratia (1899) and Sano (1900) on the human. 

Bailey (1901) published a nost important paper on the neuro-logical siae of rabies. Lis observations vere quite complete and accurate, and so they will be given at some length in this paper. Using a fixed virus which killed the animal in from seven to nine days, he ran a series of experjments killing an animal each day after the third. Three deys after the inoculation he was able to find no change in the Purkinje cells. Four days after inoculation he founa changes in these cells which he described as follows: "There is a decided reuction in the amount of chromatin substance in the cells of Burkinje, but $x_{i}^{x}$ appear normal. Nuclear changes are seen in but few of the cells, and these are of a milder grade..... Some of the cells of Purkinje show a considerable amount of chromatic substance, but in a wuch finer state of subdivision than normal: others show complete or almost complete loss of the basophile elecent, with a diffused ground substance, a finely granular blue ground substance, or the sane with a lew large granules. But their behavior and their relative numbers would indicate that the former change is a result of degeneration of the Purkinje cells which are normally rich in chromatin: while the latter results frow changes in the cells which are normally deficient in this constituent". 

In his description of the findings in his fifth and sixth day rabits he describes the cells as being wore altered then in the former case. They often show a breaking up of the nucleolus, a red staining of the large cranules of the nucleo-reticulum, the nuclear mevibrane sharply defined and deeply staining, the cell body either regular, shrunken or broken, the cytoplasm clear, or blue and granular, or homogeneous. The Nissl substance is broken up and very irregular in distribution.

In his description of the cells of those animals dying on the seventh day he says that the cells show more advanced disinterretion than the former. There are large red staining granules in the nuclei of some of the cells while in the most of them there is a coarse blue cranulation. These rranules have been identified by Dolley (1913)as unsynthetized rolk material, the penesis of depression being found in the failure of synthesis. There is very little chromatin left in the cytoplasm and it appears very auch clearer. The outline of the cell is often indistinct or irregular. There is a marked reduction in the number of the cells in a given field.

He says that the changes in his animal dying on the ninth day a more extreme than thoseppineviousfy 

When stained vith a combination stain the nucleus appears to be of a wore purplish tint and may be seen to contain large acid staining granules. The cell sutlines are often irregular. Eailey's description is so similar to my own that a mere reference to another part of this paper (see introduction) will leave no reasonable doubt that the material examined by Bailey showed just the same procrescive depression unon activity which I have described before. His work also serves as a positive check on the experiments the writer has carried on.

Willisms and Lowden (1906) noted that the"bodies", which they deccribe, viere often found in degenerating nerve cells. They note that there are certain large areas of degenerated nerve cells and that in other places the cells are not decenerated. This finding of certain cells showing degeneration is fairly a constant finding of the investigators upon the cytological side of this problem and was noted in the more advanced cases described by the writer. This degeneration, however, was in the case of my material, the end product of profound depression? 

Frothingham (1906) noted degeneration of the nerve cells in the material which he examined. He also hoted in connection with a coscription of his plates, "Some of the panglion cells are normal. s sme are partly, others entirely, replaced by now formed endothelial (?) cells. - - - From this brief description and from the appearance of the cells in his plates, I feel quite sure that the material which he studied showed depression of some of the cells and a total loss of cell in other places. Osler (1907) in his Theory and Practice of l.edicine, (probably quoting from the investigations of Babes) states, "The cells of the bulbular nuclei undergo degeneration and show various stages of chromatolysis. There is a loss of the prolongations and progressive modification with even total loss of the nuclei... Many of the cells become surrounded by a large zone of embryonal cells: degeneration of the cell follows,-.-.." Quoting from work of van Gehuchten and Nelis (1900) he says that the most merked lerions are found in the intervertebral and pheumogastric ganglia. "They consist of the atrophy, the invacion, and the destruction of the nerve cells by new formed cells,.... 

The nerve cells which are not destroyed show various degenerative changes of the protoplasm and nucleus, such as vacuolation, excentricity of the nuclei, chromatolysis, etc. In advanced cases practically all of the nerve cells way be destroyed....... " This statement of osler may be taken to represent the concensus of opinion at the present time. His description of the cells showing vacuolation (edema) , chromatolysis, progressive degenerative changes, and final destruction of the cell, certsinly is a description of cells in depression. 



\section{Summary and Conclusions.}

Bacterial toxins have a definite, diagnosticable action on the physiological activity of the nerve cells which, while it varies with the toxin used, is constant for a particular toxin. The severity of the physiological changes in the nerve cells appears to be in direct relation to the severity of the organic symptoms.

The toxins from the staphlojecocus group of bacteria has ${ }^{2}$ relatively a mild toxic effect upon the nerve cells, inducing in them, primarily, the changes of mild activity and later super-imposing a mild degree of depression.

The toxin of B. Diphtheria, however, is more toxic, inducing moderate activity early in the intoxication and profound depression later. The profound depression in the cells is approxicately in tiwe with the physical symptoms of paralysis. An analysis of this finding would lead to the assumption that the paralysis and outward menifestation of loss of functional power, which are present in the advanced disease, are secondary and dependant upon the changes in the nerve cells.

The toxin of the rabies virus is by far the most toxic in its effect upon the nerve cell of any of the 

toxins studied so far. While the primary effect on the nerve cell is a mild stimulation to function, upon this is quickly superimposed profound depression, which leads to degeneration, necrosis, and final alsappearance of the cells. The beginning of the paralysis is almost exactly coincident in time with the beginning degeneration of the nerve cells and the cell degeneration seems to stand in causal relation to this paralysis.

From these results the following conclusions are to be deduced as to the nature and physiological significance of the action of the toxins employed:

1. Bacterial toxins have a definite action upon the physiological activity of the nerve cell which is constant for that particular bacterium. The invariable action for the three bacteria investigated has been an initial excitetion followed by depression which may result in necrofiosis and cell death.

2. This action varies extensively in severity with the different toxins used.

3. The severity of the changes induced in the nerve cells by a specific toxin is airectly comparable to the severity of the general symptoms of intoxicetion manifested by the entire body. 

4. On the side of depression, so far as the work has gone, the physicel sjmptoms wanifested in an intoxication from the invasion of bacteria or frow the introduction of their toxic products are coincident in time with certain marked changes in the physiological state of the cells and in certain cases the cellular changes seem to stand in caurel relation to the constitutional changes. The most definite example of this is the correlation of cell degeneration with the paralysis in rabies. 

GENERAI BIBLT IOGEAPHY.

Dolley, D. H., - - 1911 - - The Recuperation of Nerve Cells, Journ. of lied. Res., vol. xxiv, No. 2, p. 311.

Dolley, I. H., - - 1913 - - The Morpnology or Functional Depression., Journ. of Med.. Res., vol. xxix pp. 122, ע and 124 .

Dolley, I.H., - - 1914 - - Unpublished.

Flerming, - - - 1895 - - Arch. f. mik. Anat., xlv1, 379.

v. Leriossek, - - 1897 - Arch. fur Psychiat., xxix, 345.

Mann, G., - - - 1894 - - Ztschr. f. wissenscr. Miks., xi, 479.

Verworn, M., - - - 1896 - - Erregung und Lahmung. Verhandle. d. Ges. devtsch. Naturf. u. Arzte zu Frankfort a $\mathbb{k}$. I. Theil., Ixxi11, Deutsch. Med. Woch., xxi1, 640.

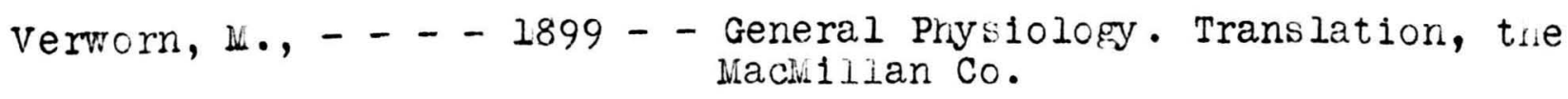

\section{DIPHTHERIA - BIBLIOGRA PHY.}

Aberecrombie, - - 1881 - $\underset{\text { prans. Internat. Med. Cong., vol. iv., }}{\text { p.61. }}$ Babes, v., - - - $1898--$ Berl. klin. Wchnuschr., Bd. xxxv, ss. Batter, F.E., - - 1898 - - pamology of Diththerial Paralysis, Brit. Med. Journ., vol. II for 1898 , p. 1540 .

B11lington, C. E., - 1889 - - Diphtheria- Its Nature and Treatment., New York, 1389, p. 66.

Bristowe, - - - 1888 - - Brit. Med. Journ., London, völ. 1, 225.

Charcot et Vulpian, -1862 - - Compt, rend. Soc. de biol., Paris, sér. 3, tome iv, p. 173.

Crocq, J. (fils), - 1896 - - Recherches expérimentales sur les altérations du systeme nerveux dans les: paralysies diphthéritiques, Paris,. Déjerine, - - - 1878 - Arch. de Phys. norm. et patr., Paris,

Déjerine, - - - 1878 - Arch. de Phys. norm. et path., Paris, Tome vi11, p. 317. 

Gaucher, - - - - 1881 - Journ. de I'anatom. de Fobin, 1881.

Gowers, - - - - 1895 - - Diseases of the Nerveous system, 2nd. Edition., vol. II, Phil., p. 914.

Hascie, - - - - 1895 - - kunch. med. Woch., Bd. xlii, p. 240.

Hocrialis, - - - 1892 - - Virchow's Arch., Bd. cxxiv, s. 226.

Katz, o., - - - - 1897 - - Arch. f.. Kinderi., stuttgart, Bd. xxili, S. 68 .

Kidd, - - - - 1883 - Med. Chir. Trans., London, 188z, vol. IXv1. p. 133 .

Kidd, - - - - - 1885 - - Iied. Chir. Trans., London, vol. lxvi, p. 136 .

Laslett, E. I., - - 1903 - - Pathology of Post-diphtheric Paralysis, Jomrn. of Path. and Bact., v111, 228.

Martin, - - - - I892(a)- Brit.Med. Journ., London, vol. I, p. 698 .

Niartin, - - - - $1892(\mathrm{~b})$ - Sup. to the local Gov. Board Rept., $1891-92$.

Mendel,. - - - - 1885 - - Neurol. Centralbl.,. Leipzig, Bd. iv, S. 128 .

Mejer, - - - - - 1881 - - Virchow's Arch., Bi. Ixxxv, p. 181.

Murawjeff, - - - - 1897 - - Arch. de méd. expér. et d'anat. path., Par1s, tome,1x, p. 1165 .

Murawjeff, - - - - 1898 - - Neurolog. Centralb1., p. 475.

Nortrrup, Wm. P., - 1902 - - Nothnagel's Incyclopedia of Practical Medicine, Pril. \& London, vol III, 55.

Dertel, - - - - 1071 - Deutsches Arch. f. klin. Wed. Le1pzig, Bd. vili, S. 242 .

oertel, - - - - 1874 - - Cyclopaedia or the Practice of Medicirie, vol. I, p. 656 .

Perrlc1 e Scagilosi, 1896 - Pisani, Palermo, No. 2.

Preisz, - - - - 1892 - - Deutsche ztschr. f. Nervenin, Leipzig, $\mathrm{Bd}$. v1, s. 95.

Quinquand, - - - - 1880 - - "Traité de chimie pathol"., Paris, 1880.

Ra1ny, H., - - - - 1900 - - On the Action of the spinal stichochrome Celis, Journ. of Path. and Bact., v1, p. $435-454$.

Ralny \& Playfair, - 1900 - - Report, Edin. Hosp. Rep., vol. v1. 

Smith, Eustace, - - 1889 - - Diseases in Children, 2nd Edition, p. 98. Starr, K. A., - - 1909 - - Organic and Functional Nerveous Iiseases, 3rd. Edition, N. Y. \& Piil., p. 232.

Thomas, J.J., - - - 1898 - Boston Med. and S. Journ., vol. cxxxviii, pr. $76,91,123$.

Vulpian, - - - - 1876 - - 'Leçons sur les maladies du syst'eme nerveux", Paris, 1876.

Wener, H., - - - - $1864-$ - Virchow's Archiv, Bd. xxi11, S. 115.

Wocinead, G. Sims, - 1898 - - Brit. Led. Journ., London, vol. II, p. 593.

FABIES - BIBIIOGRAPHY.

Babes, - - - - - 1887 - Studien iiber die Wuthkrankneit, virchow's Arcriv, . cv, p. 562 .

Babes, - - - - - 1892 - - Sur certain charectères des lésions iistologiques de la kage, Ann. de l'Inst. Pasteur, vi, p. 209.

Babes, - - - - - 1898 - - Ueber den Einfluss der verschiedenen Infectionen auf die Nervenzellen des Fückenmarks, Berliner klin. Wochenschr., pi. $6,36,56$.

Babes, - - - - - 1898 - - Sur les lésions précoces des centres nerveux dans la kage, Compt. rend. Acad. d. sc., cxxvi1, p. 776 .

Babes, - - - - - 1900 - - Les nodules rabiques et le diagnostic rapide de la kage, Presse kied., 11, p. 16s

Babes, - - - - - 1900 - - Le diagnostic rapide de la rage par l'examen microscopique du bulbe du crien mordeur., Ann. de Méd. Vétér.,. $\mathrm{x} I 1 \mathrm{x}, \mathrm{p} .252$.

Balley, F. R., - - - 1901 - - Studies on tre liorphology of Ganglion Celis in the Rabbit, Journ. of Exper. lied., $v, p .549$. .

Benedikt, - - - - -1874 - - weener med. Presse, xv, p. 617.

Benedikt, - - - - -1875 - - Virchow's Archiv, Ixiv, p. 557 .

Beneilkt, - - - - -1878 - - Virchow's Archiv, Ixx11, p. 425.

Bollinger, - - - - 1875 - Cyclopedia of the Practice of Nedicire, VOI. III, p. 433 . 

Coats, - - - - 1877 - Brit. Hed. Journ, i1, p. 866.

Crocg, - - - - 1900 - - Les lésions anatomo-patrologiques de la rage sont-elies spécifiques, Journ. de neurologie, v, p. 241 .

Culllé \& vallée, - 1900 - - Revue vétér., June 1900.

Frothirgham, L., - - 1906 - - The Rapid Diagnosis of Rabies, Journ. of Med. Fes., p. 471.

Geruciter, van, \& Nelis

$$
\begin{aligned}
& 1900 \text { - - Les L'esions histologiques de la rage } \\
& \text { crez les animaux et chez l'homme. Bull. } \\
& \text { Acad. roy. de méd. de Belg., } 4 . \text { s., xiv, } \\
& \text { p. 3i. }
\end{aligned}
$$

Gerucrten, van, \& Nelis

1900 - - Diagnostic nistologique de la rage. Ann. de méd. vétér., xlix, p. 243.

Gehuchten, van, - - 1900 - - La rage. Ann. de l'Insti. chr. de Bruxelles, vii, p. 105.

Gericrten, van, - - 1900 - A propos du diagnostic nistologique de la rage des rues. Semaine méd. p. 169. Ixem. Journ. de neurologie, Nos. $19 \& 20$. and Blill. Acad. roy. de réd. de Belg. 4.s., xiv, p. 389.

Germano \& Capobianco,1895 - - Contribution à Pristologie de la rage. frn. de l'Institut Pasteur, ix, p. 625.

Gianturco, - - - 1887 - Ricerche istologiche sulla rabbis.. Psicriatria, v, p.299.

Golgi, - - - - 1894 - - Ueber die pathologische Histologie der Rabies experimentalis. Berliner kiln. Wochenschir., p. 325.

Gowers, - - - - - - - Trans. Path. Soc. Iondon, xxv111, p. 10.

Gratia, - - - - -1899 - - Un cas de rage numaine. Bull. Soc. roy. d. sc. méd. et nat. de Bruxelles, March 6, 1889. also Clinique (Brux), 19,00, xiv, pp. 465, 481. and Ann. de méd. vétér., 1900, xi1x, p. 345.

Hebrant, - - - 1900 - - Sur les lesions de la rage chez le chien et sur le diagnostic post mortem de cette affection. Ann. de méd. vétér., xlix, p. 76; also, 1bid, xlix, p. 302, 569.

Nead, Richard, - - 1747 - A mechanical account of Poison. 4th Edition, p. 129. 



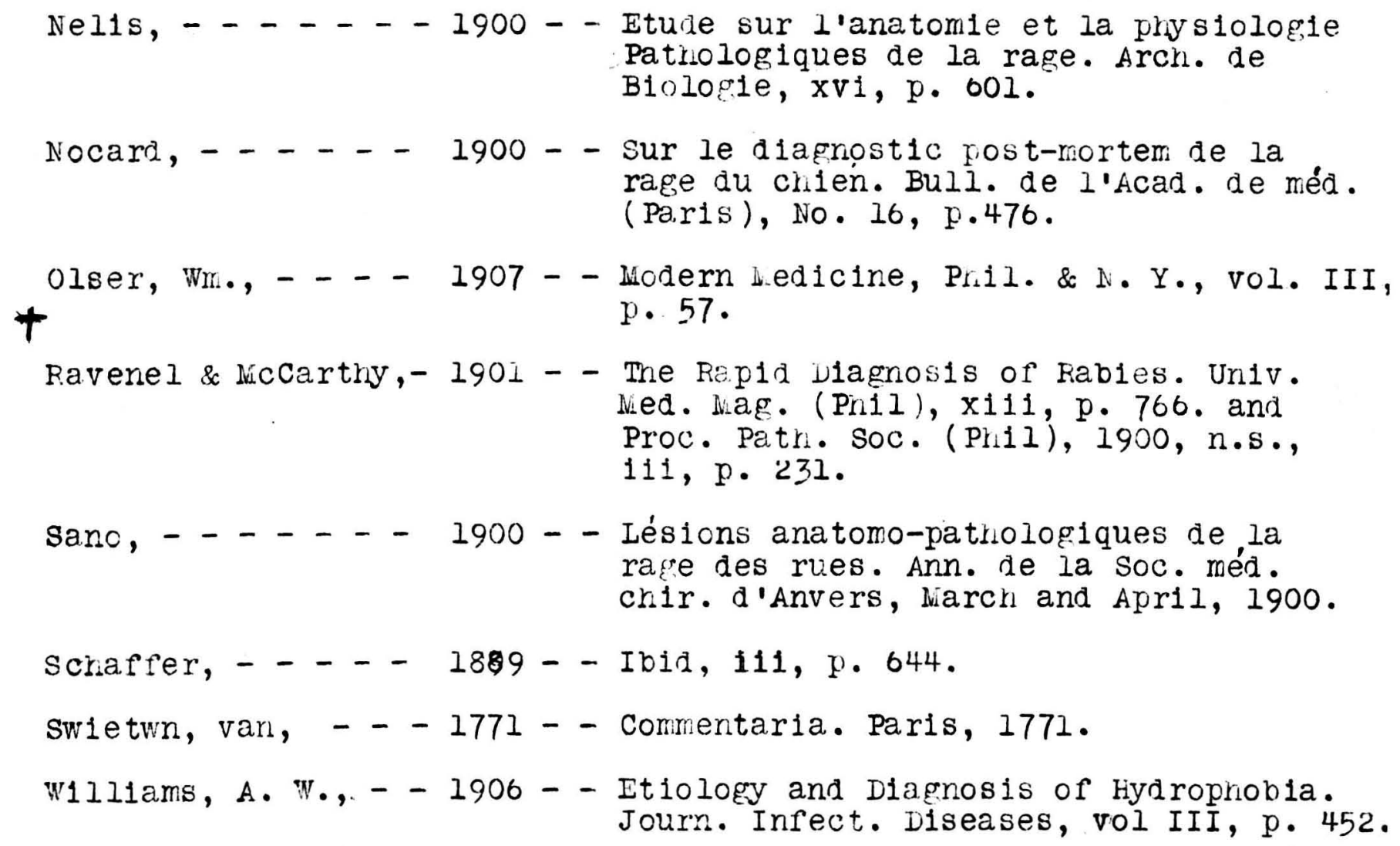

Ravenel \& kícCarthy, 1901 - - The Rapid Liagnosis of Rabies. Univ. Med. Mag. (Pnil), xi11, p. 766. and Proc. Patr. Soc. (Pril), 1900, n.s., $11 i, \mathrm{p} .231$.

Sano, - - - - 1900 - Lésions anatomo-patrologiques de la rage des rues. Ann. de la soc. méd. chir. d'Anvers, Narch and April, 1900.

Scriaffer, - - - 1889 - - Ibid, 111, p. 644.

Swietwn, varı, - - 1771 - - Commentaria. Paris, 1771.

W1lliams, A. W., - - 1906 - - Etiology and Diagnosis of Hydrophobla. Journ. Infect. Diseases, vol III, p. 452.

Gamale1a, - - - 1887 - - Ann. de l'Inst. Pasteur, 1, p. 165. Kolessnikow, - - - 1875 - - Centrabbl. f. d. med. Wissensch. p. 853.

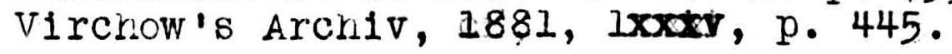

† Pollatilon \& Nepreu, 1872 - - Un cas de rage. Comptes rend. Soc. de biol., p. 132 . 









\subsection{1}

XSit

\section{$010-100951169$}

\begin{tabular}{c|c}
\hline DUE & RETURNED \\
\hline
\end{tabular}

\section{MU MAR 152013}

BOOKS MAY BE RECALLED BEFORE THEIR DUE DATES

This thesloswanever to laave this room.

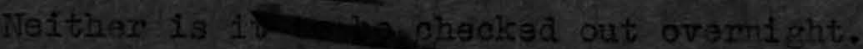

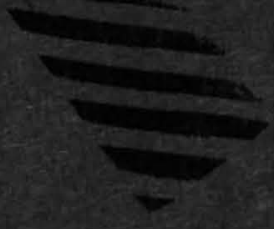




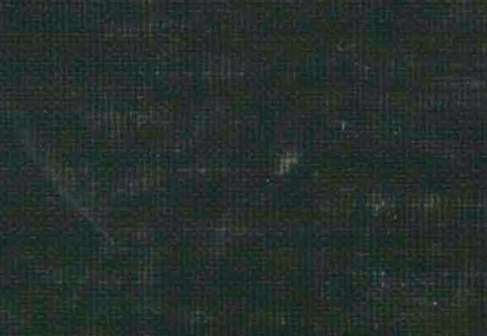

ili: 